\title{
LABOR LAW: EMPLOYER'S GRANT OF BENEFITS PRIOR TO REPRESENTATION ELECTION HELD NOT TO CONSTITUTE AN UNFAIR LABOR PRACTICE
}

SEcrion 8 (a) (I) of the Taft-Hartley Act makes it an unfair labor practice for an employer "to interfere with, restrain, or coerce employees" 1 in the exercise of their statutory right to form labor organizations, as guaranteed by section 7 of the act. ${ }^{2}$ In the recent case of NLRB v. Exchange Parts Co., ${ }^{3}$ the Court of Appeals for the Fifth Circuit held that an employer's unconditional grant of benefits to employees during a pre-election period did not violate the act, notwithstanding a finding that the employer conferred the benefits for the purpose of influencing the outcome of the representation election. In so holding, the court enunciated a rather disparate and restrictive interpretation of when increased benefits will constitute employer interference under section 8 (a) (I).

The Exchange Parts case arose when an employer instituted a revamped vacation system and a different method for calculating overtime during the interval between issuance by the National Labor Relations Board of an order for a representation election and the time the election took place. ${ }^{4}$ After company employees rejected the union at the polls, ${ }^{5}$ the trial examiner and the NLRB both found that the company had committed an unfair labor practice by granting the benefits with the intent of influencing the outcome of the

${ }^{1}$ National Labor Relations Act $\$ 8$ (a) (I), 49 Stat. 452 (1935), as amended, 29 U.S.C. $\S 158$ (a) (1) (1958).

"Employees shall have the right to self-organization, to form, join, or assist labor organizations, to bargain collectively through representatives of their own choosing, and to engage in other concerted activities for the purpose of collective bargaining or other mutual aid or protection, and shall also have the right to rcfrain from any or all of such activities except to the extent that such right may be affected by an agreement requiring membership in a labor organization as a condition of employment as authorized in section 158 (a) (3) of this title." National Labor Rela. tions Act $\$ 7,49$ Stat. 452 (1935), as amended, 29 U.S.C. $\$ 157$ (1958).

${ }^{3} 304$ F.2d 368 (5th Cir. 1962), denying enforcement of 131 N.L.R.B. 806 (1961), petition for cert. filed, 31 U.S.L. WEEK 3157 (U.S. Oct. 18, 1962) (No. 537).

'The Board also found that the employer committed an unfair labor practice by timing the announcement of the date of a previously granted paid holiday so as to influence the election. The court, however, determined that there was no substantial evidence on which the Board could base such a conclusion and overruled the Board's finding on this point. The duty of the circuit court to accept a finding of fact made by the Board for which there is substantial evidence is stated in note 8 infra.

Brief for Petitioner, p. 6. 
election. ${ }^{\circ}$ The employer refused to abide by the Board's order to cease and desist from granting further benefits pending the outcome of a new election, ${ }^{7}$ and the Board petitioned the Fifth Circuit for enforcement. The court accepted the finding of fact that the benefits were granted for the purpose of influencing the election, ${ }^{8}$ but concluded that enforcement should be denied, since the benefits actually and unconditionally had been granted and did not, therefore, meet the court's newly, formulated test requiring "objective evidence of restraint or coercion."

The NLRB has traditionally subjected pre-election grants of benefits by employers to careful scrutiny.10 While refusing to characterize grants of benefit as per se interference with elections, ${ }^{11}$ the Board has applied two ostensibly conficting tests in determining whether such grants violate the act. One test makes it unlawful for an employer to grant benefits with the intent to induce employees to reject union representation. ${ }^{12}$ The second test disregards the purpose of the employer's act and looks to its effect. More exactly, a grant of benefit is unlawful if a reasonable inference can be drawn that such conduct tended to interfere with the employee's right to a free choice. ${ }^{13}$ Upon analysis, it is submitted that the apparent inconsistency of such a double faceted approach resolves itself into alternative requirements of proof on the part of complainants. Thus if increased benefits did influence the election, the question of

\footnotetext{
- Exchange Parts Co., 131 N.L.R.B. 806 (1961).

T The Board is empowered to issue a cease and desist order against any employer found guilty of an unfair labor practice, but must petition a court of appeals to enforce such order in the event that it is not honored by the offending party. National Labor Relations Act $\S \S 10$ (c), (e), 49 Stat. 454 (1935), as amended, 29 U.S.C. $\$ \S 160$ (c), (e) (1958).

$B$ "The findings of the Board with respect to questions of fact if supported by substantial evidence on the record considered as a whole shall be conclusive." National Labor Relations Act $\$ 10$ (e), 49 Stat. 454 (1935), as amended, 29 U.S.C. $\$ 160$ (e) (1958). For a discussion of the substantial evidence rule, see Green, Evidence of Unfair Labor Practices under the Taft-Hartley Act, 26 N.C.L. REv. 253 (1948).

- 304 F.2d at 372.

10 "[I]nterference is no less interference because it is accomplished through allurements rather than coercion, when, as here, the system is employed to stem a tide of organization ...." Western Cartridge Co. v. NLRB, 134 F.2d 240, 244 (7th Cir. 1943). ${ }_{21}$ See, e.g., Glosser Bros., Inc., 120 N.L.R.B. 965 (1958); Bata Shoe Co., 116 N.L.R.B. 1239 (1956); United Screw \& Bolt Corp., 91 N.L.R.B. 916 (1950).

12 Hudson Hosiery Co., 72 N.L.R.B. 1434, 1436 (1947). Accord, Pinkerton Folding Box Co., 121 N.L.R.B. 1308 (1958); Bermuda Knitwear Corp., 120 N.L.R.B. 332 (1958); Automotive Supply Co., 119 N.L.R.B. 1074 (1957).

${ }^{13}$ See, e.g., NLRB v. Ford, 170 F.2d 735, 738 (6th Cir. 1948); American Freightways, Co., 124 N.L.R.B. 146, 147 (1959).
} 
motive is immaterial; but if it cannot be proved that the benefits influenced the election, a violation may be found by a showing of improper motive. Under either test, the rationale seems to be that while unilateral grants of benefit are permissible under exceptional circumstances, such benefits are inherently antithetic to the purposes of section 8 (a) (l) and usually should be prohibited. This conflict arises, not because such grants are necessarily restrictive or coercive, but because they substantially interfere with employee rights by demonstrating and emphasizing that "there is no necessity for a collective bargaining agent"14 and, accordingly, that resort to selforganization is unnecessary. ${ }^{15}$

Applying these tests, the Board and courts consistently have held that granting benefits constitutes an unfair labor practice where the benefits were promised or conferred upon the express or implied condition that the employees abandon the union or reject it at the polls during a representation election. ${ }^{18}$ Benefits given to only a few employees within a unit have been held to approach the tenor of bribes. ${ }^{17}$ Furthermore, benefits conferred by employees engaged in other questionable activities, such as interrogations, threats, or espionage, have been held to be unfair labor practices and further increases have been prohibited. ${ }^{18}$ The end result of the approach

14 May Dep't Stores Co. v. NLRB, 326 U.S. 376, 385 (1945).

${ }^{15}$ See NLRB v. Pyne Molding Corp., 226 F.2d 818 (2d Cir. 1955); Joy Silk Mills, Inc. v. NLRB, 185 F.2d 732 (D.C. Cir. 1950) cert. denicd, 341 U.S. 914 (1951); NLRB v. Bailey Co., 180 F.2d 278 (6th Cir. 1950); Joslin Dry Goods Co., 118 N.L.R.B. 555 (1957).

${ }^{10}$ Medo Photo Supply Corp. v. NLRB, 321 U.S. 678 (1944) (wage increase conferred to induce employees to leave union); NLRB v. W. T. Grant Co., 199 F.2d 711, 712 (9th Cir. 1952) (benefits promised "to dampen the ardor of the employees for union affiliation"); Gorbea' Perez \& Morell, S. en C., 133 N.L.R.B. 362 (1961) (promise of benefits conditioned on maintenance of nonunion status quo).

17 Coca-Cola Bottling Co., 132 N.L.R.B. 481 (1961); Pinkerton Folding Box Co., 121 N.L.R.B. 1308 (1958). In recognition of this evil, the Landrum-Griffin Act of 1959 amended $\$ 302$ of the Taft-Hartley Act and made it unlawful for any employer to pay "to any employee or group or committee of employees of such employer employed in an industry affecting commerce in excess of their normal compensation for the purpose of causing such employee or group or committee directly or indirectly to influence auy other employees in the exercise of the right to organize and bargain collectively through representatives of their own choosing." Labor-Management Reporting and Disclosure Act (Landrum-Griffin Act) $\$ 505$ (a) (3), 73 Stat. 537.38 (1959), 29 U.S.C. $\$ 186$ (Supp. II, 1961), amending Labor Management Relations Act $\$ 302$ (a), 61 Stat. 157 (1947).

${ }^{18}$ See NLRB v. West Coast Casket Co., 205 F.2d 902 (9th Cir. 1953) (interrogations); NLRB v. Crown Can Co., 138 F.2d 263 (8th Cir. 1943) (threats); M. H. Ritzwoller Co. v. NLRB, 114 F.2d 432 (7th Cir. 1940) (threats and interrogations); Avildsen Tool \& Machs., Inc., 112 N.L.R.B. 1021 (1955) (threats). 
taken in these cases seems to be that a unilateral grant of benefits by an employer will be an unfair labor practice, unless the employer can justify the increase on grounds unrelated to the election. Thus, the employer has been allowed to show that benefits were granted in accordance with a policy established antecedent to the pre-election period. ${ }^{19}$

Exchange Parts rejected the established tests used by the Board and required "objective evidence of restraint or coercion"20 to be shown before an added benefit would support an unfair labor practice charge. The decision thereby summarily stripped the words "interfere with" of any legal significance, despite their express recital in the statute in conjunction with "restrain" and "coerce." The court, emphasizing that the increase in benefits in no way deprived the employees of their freedom to vote for the union, reasoned that the three prohibitions recited in section 8 (a) (1) are in apposition with one another and do not comprehend "three separate categories"21 of unfair employer actions. Under this newly espoused test, interference, to be violative of the act, must result in substantial pressure that embodies coercion or restraint. By thus postulating duress as an essential element of a section 8 (a) (1) violation, not only are the tests utilized by the Board rejected, but there is a wholesale denial of the efficacy of the concept that section 8 (a) (I) can be violated by an employer demonstrating and emphasizing that collective bargaining is unnecessary.

From an analysis of prior cases, however, the court determined that its decision was not inconsistent with precedent. Drawing a distinction between promised and conferred benefits, it concluded that prior cases have found the former unlawful because they force employees to choose between the employer's immediate offer and the more remote benefits to be derived from union membership. While the court is correct in concluding that promised benefits have been

\footnotetext{
${ }^{10}$ See, e.g., NLRB v. Cleveland Trust Co., 214 F.2d 95 (6th Cir. 1954) (increased wages to meet inflationary rise in cost of living); NLRB v. W. T. Grant Co., 208 F.2d 710 (4th Cir. 1953) (increased wages under policy of paying same wage scale as rival store); Hudson Optical, Inc., 122 N.L.R.B. 149 (1958) (wage increase following pattern of annual wage increases). The burden is clearly on the employer to show that the conferring of benefits was governed by factors unrelated to the elcction. See Glosser Bros., 120 N.L.R.B. 965 (1958); Bata Shoe Co., 116 N.L.R.B. 1239 (1956); Knickerbocker Mfg. Co., 107 N.L.R.B. 507 (1953).

${ }_{20} 304$ F.2d at 372. (Emphasis added.)

21 Id. at 374. But sce Myers, "Interference" in Labor Relations Acts, 19 B.U.L. REv. 208 (1939).
} 
the inducement in numerous past cases, ${ }^{22}$ there is no paucity of cases wherein conferred benefits have been held to constitute unfair labor practices..$^{23}$ It is submitted, furthermore, that the question of a violation has never turned on a distinction between the two. Under the court's test, requiring that restraint or coercion be shown, such a distinction may be viable, since promises may exert considerably more direct pressure on employees than conferred benefits. ${ }^{24}$ But from the viewpoint of the Board, unfair practices take place whenever the employer demonstrates that employee self-organization is unnecessary, and the distinction loses its significance. Applying interference as the criterion, conferred and promised benefits both would seem to have the unlawful effect of emphasizing the futility of resorting to a bargaining agent.

With regard to cases wherein conferred benefits were found to violate the act, the court concluded that such benefits were held unlawful because they were part of an "overall scheme" 25 of illegal acts which put substantial pressure on the employees. While courts have made reference to the presence of other unfair labor practices, the significance attached to them has been to evidence the employer's motive in granting the increase. ${ }^{28}$ Presumably, if, as was the case in Exchange Parts, the intent of the employer could have been shown without reference to other unfair practices, then the presence of other unfair practices would have been immaterial in determining whether an increased benefit violated section 8 (a) (1).

Though departing from previous Board interpretation and the apparent meaning of the statute, the court's interpretation of the words "interfere with" find support in the legislative history of a parallel section adopted twelve years later in the Taft-Hartley Act

\footnotetext{
22 See, e.g., Joy Silk Mills, Inc. v. NLRB, 185 F.2d 732 (D.C. Cir. 1950); NLRB v. Bailey Co., 180 F.2d 278 (6th Cir. 1950).

${ }^{23}$ See NLRB v. Jamestown Sterling Corp., 211 F.2d 725 (2d Cir. 1954); NLRB v. Louisville Container Corp., 209 F.2d 654 (6th Cir. 1954); NLRB v. Valley Broadcasting Co., 189 F.2d 582 (6th Cir. 1951); NLRB v. Crown Can Co., 138 F.2d 263 (8th Cir. 1943); Standard Fittings Co., 133 N.L.R.B. 928 (1961).

ss Promised benefits, because they lack the finality and degree of commitment by the employer found in a benefit actually conferred, might make an employec feel that he is placed in a situation wherein he must choose an alternative favored by the employer in order to gain what has been promised but not granted.

25304 F.2d at 373 .

${ }^{30}$ NLRB v. Pyne Molding Corp., 226 F.2d 818 (2d Cir. 1955) (illegal firing and interrogating of employees); NLRB v. West Coast Casket Co., 205 F.2d 902 (9th Cir. 1953) (threat to close plant); Joy Silk Mills, Inc. v. NLRB, 185 F.2d 732 (D.C. Cir. 1950) (threats and illegal interrogations).
} 
of 1947. This act added section 8 (b) (1) to the Wagner Act of 1935, making it an unfair labor practice for a labor organization to "restrain or coerce"27 either employees or employers in the exercise of their respective rights during an organizational period. In explaining the obvious diversity between the language in section 8 (a) (1) regarding employers and section 8 (b) (1) regarding labor organizations, the House Conference Report expressed the joint committee's belief that the NLRB heretofore had not found interference where there was not also restraint or coercion. ${ }^{28}$ The Report went on to admonish that omission of the words "interfere with" from section 8 (b) (1) was not to be construed so as to give independent meaning to those words in the previously enacted section 8 (a) (1). Although the conclusion regarding the Board's interpretation of section 8 (a) (1) is open to question, ${ }^{29}$ the plain inference to be drawn from the language in the Report is that forthwith interference should not be separately categorized from restraint or coercion.

The weight to be attached to the expression of intendment found in the Conference Report is a problem difficult to resolve for a number of reasons. What Congress enacted was the legislation itself and not the Conference Report. Indeed, the statement made by the 1947 Report on the meaning to be given the then twelve year old section 8 (a) (1) is the purest form of dicta. Moreover, it is a reasonable inference that Congress intended to give distinct legal significance to the phrase "interfere with," particularly in light of its deliberate omission from section $8(\mathrm{~b})(1)$ and the failure of Congress to eliminate it from section 8 (a) (1) when presented with the clear opportunity to do so in 1947.

However, there are policy considerations which may tend to substantiate the interpretation given the statute by the Conference Report and by the Fifth Circuit in the instant case. If the labor legislation of the past three decades has been inspired by a desire to strike a workable power balance between labor and management, ${ }^{39}$

\footnotetext{
${ }^{27}$ Labor-Management Relations Act $\$ 101,61$ Stat. 141 (1947), 29 U.S.C. $\$ 158$ (b) (1) (1958), amending National Labor Relations Act § 8, 49 Stat. 452 (1935).

${ }^{28}$ H.R. Conf. Rep. No. 510, 80th Cong., Ist Sess. 43 (1947). The House Conference Report is cited herein to lend support to the position of tbe court in the instant case. It is brougbt to the attention of the reader, however, that the Report is not cited by the court itself in the course of its decision.

${ }^{20}$ See 54 Harv. L. REv. 1036 (1941).

${ }^{\circ 0}$ See Farmer, The Taft-Hartley Act and the Balance of Power in Labor Relations, 51 W. VA. L.Q. 141 (1949).
} 
then it is not unreasonable for the court to assume that the language of the act was intended to be flexible in order to accomplish this purpose. Because labor, through legislation and its own efforts, has achieved a position of redoubtable strength on the national scene, strict application of statutory prohibitions against management, under present conditions, might tend to create an imbalance favorable to labor and if so would be inconsistent with the fundamental -objectives of the act. Viewed in this perspective, the court's tenuous analysis of statutory language and judicial precedent may have achieved a result pragmatically sound and reasonably within the confines of the spirit of the statute. 